\title{
Anticipating the Difficulties of Microfinance Institutions: An Early Warning Model Applied to the Togolese Context
}

\author{
Maïpa Pakidame', Komivi Ogbone², Yao Messah Kounetsron ${ }^{2}$ \\ ${ }^{1}$ MFIs'Unit of Control and Monitoring, Ministry of Finance and Economics, Lomé, Togo \\ ${ }^{2}$ University Institute of Technology of Management, Université de Lomé, Lomé, Togo
}

Email address:

pakmonguipa@yahoo.fr (M. Pakidame),odavy2000@gmail.com (K. Ogbone), messahyao@gmail.com (Y. M. Kounetsron)

\section{To cite this article:}

Maïpa Pakidame, Komivi Ogbone, Yao Messah Kounetsron. Anticipating the Difficulties of Microfinance Institutions: An Early Warning Model Applied to the Togolese Context. International Journal of Business and Economics Research. Special Issue: Microfinance and Local Development. Vol. 9, No. 4, 2020, pp. 234-240. doi: 10.11648/j.ijber.20200904.20

Received: March 30, 2020; Accepted: June 22, 2020; Published: July 22, 2020

\begin{abstract}
The Decentralized financial system (DFS) is a sector in growth in developing countries. It offers financial services to actors rejected by formal banks because of their risk. therefore, a strict monitoring of this sector is needed to anticipate and avoid the bankruptcies of DFSs. In this context, an early warning model is a feasible solution. The aim of this paper is to develop a model of alert capable of predicting the difficulties of microfinance institutions. Data processed from 49 DFSs over 5 years led to a model explaining up to $80 \%$ of the likelihood of bankruptcy. Statistically positive results show that any increase in the portfolio at risk, the provisions on outstanding loans and the provisions on total assets leads to an increase in the probability of difficulty for the DFSs, thus increasing its insolvency risk while any increase in the equity risk coverage ratio, the operating income on owner's equity, the loan coverage by deposits ratio, the profit margin and the outstanding deposits on total assets leads to a decrease in the probability of default for the DFSs.
\end{abstract}

Keywords: Microfinance, DFS, Difficulties, Model, Early Warning

\section{Introduction}

The sector of Decentralized Financial Systems (DFS) is one of the riskiest financial sectors in Togo for two main reasons. The first risk relates to the players that drive the sector. The clients in these microfinance institutions are, for the most part, economic agents marginalized by the banking system because of the two significant risks they usually incur. First, these clients own informal businesses that lack, according to banks, reliable information systems. The survival of these production units remains strongly linked to the skills of their managers who have full control over their company's resources. The second risk factor pertains to the governance system of the DFSs.

In Togo, as of December 2013, the classic banking system amounted to 671,451 members, representing about $11.2 \%$ of the population (report of the banking commission 2013) while DFS's members amounted to 671,451 accounting for $23.73 \%$ of the population (CAS-IMEC ${ }^{1}$ ). From 2001 to 2003,

\footnotetext{
${ }^{1}$ Unit in charge of the support and monitoring of MFIs in Togo
}

54 approved DFSs collapsed leaving depositors with a loss of 9 billion XOF (about USD 15,000,000) (CAS-IMEC).

In Togo, the DFSs, for the most part, take the form of mutual entities or cooperatives. Consequently, the governance bodies consisting of the Boards of Directors, the Supervisory Boards and the Credit Committees are composed of the cooperators who are at the same time clients of the MFIs. These clients, who are informal for the most part, do not have the skills required to ensure the proper management of these institutions. As a result, DFSs are dominated by excessively-empowered leaders of the executive body and this may lead to economic slippages.

Given the current importance of the sector in terms of the growing volume of activity and risks of bankruptcy with generally insufficient liquidity to cover the depositor's demands, public authorities feel the urgency to take preventive measures to monitor the sector. Therefore, a central question that needs to be addressed is how to anticipate bankruptcies in the microfinance sector and which indicators can help to warn, early enough, on the difficulties of DFS. It is also imperative to ascertain if the current 
monitoring indicators used by the supervisory authorities and the Central bank of West African States are relevant. So, this study tests the predictive power of a few indicators that reflect the financial health of DFS while assessing bankruptcy.

This paper uses a logit model to explain, through CAMEL ${ }^{2}$ accounting ratios, the probability of default of MFIs. The findings provide regulators and supervisors with serious policy implications in taking proactive prudential actions and enforcing the regulatory controls in the MFI system.

This article has three sections. In the first section, the summary on the anticipation of bankruptcies is presented. Section two outlines the methodological choices of the study. Finally, the third section presents the results and discussions followed by a conclusion to the paper.

\section{The Determinants of Financial Institutions' Failure and Early Warning Models}

Several studies aimed at identifying the determinants of institutions' failure and developing early warning.

\subsection{Banks’ Determinants of Bankruptcy}

Crises are generated by the combination of several factors, both financial and macroeconomic (Hardy and Pazarbasioglu [11], Eichengreen and Arteta [8]). Sinkey [17] has identified in the American context, the quality of assets, as a determinant of banking crises. A broad study by Martin [13] on 5,700 banks highlighted the importance of the solvency ratio and credit share in the total asset amounts of these institutions.

Ahumada and Budnevich [2] concluded that the ratio of outstanding debts is one of the relevant indicators of the difficulties faced by financial institutions. Thus, the Office of the Controller of the Currency [O.C.C] [15] conducted a study with focus on the characteristics of US financial institutions that failed in the 1980s. This study found that the poor quality of assets is the main cause of failure. Therefore, the responsibility of the managers of the institutions is engaged. Mismanagement of risks is thus considered the main source of the difficulties faced by financial institutions. The study thus distinguishes four main factors related to failing banks. These include the inadequacy or absence of credit policy, the inadequacy of the control and monitoring system, the inadequacy of methods relative to identification of doubtful or overdue loans, and the excessive concentration of decision-making powers.

Llewellyn [12] also conducted a study of the main factors behind crises in financial systems. His conclusion emphasized common problems experienced by the banking

\footnotetext{
2 CAMEL (S) is an acronym consisting of six (06) variables on which banks are evaluated namely, Capital adequacy, Asset quality, Management quality, Earning ability, Liquidity position, Sensitivity to market risk introduced in
} 1997 industry around the world. They include the inefficiency of the analysis process and that of the management and control poor supervision -, the weakness or the perversity of the incentive structure - deficiency in information transmission -, and the inadequacy of governance. Thus, excessive risktaking in a financial institution is caused by shortcomings in management and a credit risk control deficit.

Excessive credit risk and poor governance are the main difficulties plaguing bank institutions. Yet, the same factors negatively influence MFIs as well. In the Vietnamese microfinance industry, Ayayi [5] positively correlate age in business, management and strategy, systems and reporting, internal and operational controls, and active government constructive regulation with good financial stand of MFIs. He also noticed that write-offs are a good determinant of MFI's credit risk. According to Ayele [6], Debt-to-Equity ratio inversely relate with viability of MFIs as revenues earned therefore struggle to outweigh operational costs and debt costs from commercial loans and/or deposits. Using a qualitative approach and the ethnomethodology, PutuAstawa [16] finds that performance measurements through CAMEL must be added to Bali MFI's ability to support religious activity and culture.

Even though the findings in the preceding studies are not limited to the banking sector, they still suggest the lack of studies in this regard in the African context and, specifically, in the microfinance industry. The above studies do not also specify how each identified factor influences the likelihood of going bankrupt or not. Early warning models try to fill this gap by taking an anticipatory approach.

\subsection{Early Warning Models}

Alert systems facilitate the identification of institutions and high-risk activities that require close monitoring. They thus enable the supervisory authorities to justify their actions towards the institutions in difficulty and facilitate their activities. There are several types of systems, namely:

1. Rating systems for banks,

2. Analysis systems for homogeneous groups,

3. Comprehensive assessment systems for risks in the banking system, and

4. Statistical and econometric models.

The early warning systems put in place differ from one country to another. Using a set of financial ratios, these models make it possible to assess the financial health of a banking institution. The scores obtained inform the classification of banks into two groups: healthy or unhealthy. Rating systems are specifically set up by the regulatory authorities to monitor banks' financial strengths. The ratios used to rate financial institutions were processed from data transmitted by the banks and data collected during controls. The majority of predictive banking difficulty models are part of the CAMEL (S) system.

Several rating systems were established in many countries, namely the SAAB (Système d'Aide à l'Analyse Bancaire), the TRAM (Trigger Ration Adjustment Mechanism), the RATE (Risk Assessment Tools and Evaluations) in England, 
the RAST (Risk Analysis Support Tool) in the Dutch system and the BAKIS (Bakered Information System) in Germany. Similarly, the supervisory authorities have also managed to set up systems to predict banking problems such as the SEER (System for Estimating Examination Ratings) in the United States of America.

Angora et Tarazi [4] suggested an early warning system to the WAEMU (West African Economic and Monetary Union) countries mostly based on macroeconomics variables. The authors recognized that their model drives a better value when taking into consideration the variable "importance of deposits" on the balance sheets of banks.

Among the different studies carried out within the microfinance industry in Togo, only that of N'Dassim [14] consisted of classifying MFIs into two groups based on financial ratios (liquidity, profitability and solvency). However, N'Dassim's [14] study does not provide grounds to assess the probability of default. Likewise, Adokpo [1] studied the contribution of owner's equity consolidation to the control of the insolvency risk of microfinance institutions without proposing a predictive model of difficulty. At the Central bank of West African States (BCEAO) level, prudential standards applicable to MFIs have been defined. They are based on a certain number of ratios which facilitate the monitoring and control of the activities of microfinance institutions in order to avoid financial slippages. These are:

1. The mitigation of risks to which an institution is exposed

All the risks (net amounts of provisions and security deposits) taken by a DFS cannot exceed twice its internal and external resources. The goal is to limit excessive risk taking.

2. The coverage of the medium- and long-term assets by non-current resources

This ratio aims to avoid excessive transformation of current-resources on demand into non-current assets; MFIs must finance all of their fixed assets by non-current resources. The minimum standard required is $100 \%$ coverage of fixed assets by non-current resources.

3. Limiting loans to managers and staff

To prevent the risk of concentrating loans and commitments to managers and staff of DFS, the proportion of resources that can be dedicated to them has been set at $10 \%$ of owners' equity. This ratio also aims to control the loans to managers.

4. Limiting the risks taken on a loan

Compliance with this ratio avoids the concentration of risks on a single member whose insolvency could cause difficulties to the DFS. The ratio is set to a maximum of $10 \%$ of owners 'equity.

5. The liquidity standard

It measures the institution's ability to meet its current liabilities, in other words to honor its short-term liabilities with its short-term assets ( 3 months maximum). The standard coverage ratio is set to a minimum of $100 \%$ for MFIs that collect savings and $60 \%$ for those that do not collect.

6. The limitation of operations other than savings collection and loaning activities

This standard ratio aims to avoid affecting clients' deposit to activities other than the main activity of the institution which is credit. The ratio of the amount spent on other activities over the total savings collected must not exceed $5 \%$.

7. The constitution of legal reserves

This constitution allows for the strengthening of the MFI's owner equity. It is fed by an annual deduction of at least $15 \%$ from the income before distribution of dividends for each financial year, after deduction of any loss carried forward.

8. The capital structure standard

This provision aims to guarantee a minimum solvency with regard to the institution's commitments. It is determined by the ratio of total shareholder's equity over total asset. The minimum required is $15 \%$.

9. The limitation of equity investments

It aims to limit the allocation of the institution's funds for investments in securities of other companies. The standard is set to a limit of $25 \%$ of shareholder's equity.

There is a need to go further than monitoring and controlling performance in the very risky sector of DFSs. The establishment of an early warning system is necessary because it will make it possible to anticipate the difficulties of these institutions and also to assess the relevance of current tools deployed for monitoring the sector.

\section{Methodology}

This study sample is drawn from the CAS-IMEC (Cellule d'Appui et de Suivi des Institutions Mutualistes ou Coopératives d'Epargne et de Crédit)'s database. The data used are extracted from reporting documents including the balance sheets, the income statements and the footnotes of authorized DFS operating in Togo and having regularly transmitted their financial information. Due to the absence of financial data about some DFSs and to the irregular transmissions of financial statements, the final sample consists of the 49 DFSs for which data were available for five (05) consecutive years from 2009-2013. The selected sample represents approximately $50 \%$ of the entire industry over the study period and $95 \%$ of the gross asset, the outstanding deposit and the industry credit.

\subsection{Banks'Determinants as Measures of Financial Institutions' Bankruptcy}

The data in our sample were classified into two (02) groups. The first group comprises a set of observations that do not meet the capitalization standard while the second group is the one that does. Thus, this classification leads to adopt for the rest of the study, a binary or dichotomous qualitative variable as the explained variable and financial indicators or ratios as the explanatory variables.

\subsubsection{Endogenous Variable}

Most DFS experiencing difficulties are those that are subject to risks of insolvency. The creditworthiness of a DFS 
is assessed on the basis of its capitalization ratio. Therefore, this study assumed that a $15 \%$ capitalization ratio is the minimum standard for a DFS to be considered solvent and financially healthy.

We consider that a DFS is in difficulty when its equity capital structure ratio is $<15 \%$ and a DFS is not in distress otherwise. The explained variable (Y) is defined as follows:

$\mathrm{Y}=1$ if the DFS is in difficulty or in financial distress (undercapitalized);

$\mathrm{Y}=0$ if the DFS is healthy (capitalized).

\subsubsection{Exogenous Variables}

The explanatory variables chosen in our model are derived from the CAMEL accounting ratios known as the most used to assess the financial health of financial institutions. These are prudential indicators published by the International Monetary Fund (IMF) that determines the strength of the financial institutions (Evans, Leone, Gill and Hilbers, [9]). They also selected considering the warning standards applicable to MFIs and recommended by the Central bank of West African States to monitor their financial health. Moreover, the theoretical and empirical literature on the one hand and the availability of data on the other hand ultimately influenced the selection of explanatory variables (Demirgüc-kunt and Detragiache, [7]; Gonzalez-Hermosillo, [10]).

1. The equity risk's coverage ratio (ERCR)

It measures the adequacy of the MFI's own funds relative to the risks linked to the credit activity. To protect itself from any insolvency risk to which the MFI is exposed when allowing loans, shareholder's equity must vary at the same scale as the volume of loans granted. This ratio is one of the best factors explaining the solvency of an institution. The financial strength of an institution is assessed based upon its own funds.

$$
E R C R=\frac{\text { Owner' }^{\text {equity }}}{\text { total loans }}
$$

2. The Portfolio at Risk (PAR)

It measures the quality of the credit portfolio of MFIs. An increase in overdue loans compared with the total gross loan portfolio is a worrying signal about the survival of the MFI. Most institutions that have a degraded loan portfolio are very likely to be in trouble. This reflects the regulation imposed to MFI limiting the default risk taken on significant single loans.

$$
P A R=\frac{\text { Outstanding loans with arrears }}{\text { total gross loan portfolio }}
$$

3. The loans' provisions over outstanding loan (LPOL) and the loans' provision over total assets (LPTA)

This ratio helps assess the quality of management of MFIs in terms of loans allowed. The deterioration of the credit portfolio must be noted by the constitution of a provision. The more the loans are not paid, the greater the provisions made.

$$
\begin{gathered}
\text { LPOL }=\frac{\text { Loan Provision }}{\text { Outstanding Loan }} \\
\text { LPTA }=\frac{\text { Loan Provision }}{\text { Total asset }}
\end{gathered}
$$

4. Operating income over owner's equity (OIOE) and profit margin (PM)

These are variables that assess yields. The higher the risk, the higher the expected return. As a result, MFIs are more likely to honor their obligations if they are profitable. These explanatory variables align with the $15 \%$ legal reserve requirement imposed to MFI. The more profitable is the MFI the more solvent it becomes and the more reserve it may make.

$$
\begin{gathered}
O I O E=\frac{\text { Operating income }}{\text { owner's equity }} \\
P M=\frac{\text { Operating margin }}{\text { Operating income }}
\end{gathered}
$$

5. Outstanding deposits over total assets (ODTA) and loans coverage by Deposits (LCD)

These ratios measure the level of liquidity of MFIs. When they have enough long-term resources to finance their long-term assets, MFIs have the financial capacity to overcome the risk of insolvency. These ratios also align with the regulation of the DFS's sector to affect deposits to assets and loans financing so that they can avoid financial troubles.

$$
\begin{aligned}
\text { ODT } A & =\frac{\text { Outstanding deposits }}{\text { total assets }} \\
L C D & =\frac{\text { Outstanding deposits }}{\text { outstanding loans }}
\end{aligned}
$$

\subsection{Presentation of the Basic Model}

The early warning model is based on an approximation of the probability of switching from a phase of resilience to a phase of financial vulnerability. The inadequacy of the linear model leads to modeling not the dependent variable $\mathrm{Y}$ which is binary, but the probability that it takes the value 1 or 0 .

1. $Y=1$ in case of difficulty if $Y_{i t}^{*} \geq 0$;

2. $\mathrm{Y}=0$ otherwise if $Y_{i t}^{*}<0$.

Next, we assume that the variable $Y_{i t}^{*}$ depends linearly on a number of exogenous variables $X_{i t}$ for an individual $i$ at a period $\mathrm{t}$; $\mathrm{i}=1$ to 49 and $\mathrm{t}=2009$ to 2013 . We seek to explain the undercapitalization which is a signal of difficulties. The Logit model is written in the following form where it is assumed that the error follows a logistic distribution. The computed probability of $\mathrm{Y}=1$ is:

$$
P\left(Y_{i t}=1\right)=P\left(Y_{i t}^{*} \geq 0\right)=F\left(\beta^{\prime} X_{i t}\right)=\frac{\left(\beta^{\prime} X_{i t}\right)}{1+\left(\beta^{\prime} X_{i t}\right)}
$$

where $\mathrm{F}$ is the logistic distribution function with an expected 
value of zero and a variance of $\sigma=\frac{\pi}{\sqrt{3}}$ and $\beta^{\prime}$ is the matrix of the explanatory variables and the constant term.

\section{Results and Discussions}

Analyzing the regression results reveals a powerful model that minimizes prediction errors but provides good signals.
McFadden's coefficient of determination $\mathrm{R}^{2}$ indicates that the probability of difficulty explained by the model is 80.94\%. The Pearson and Hosmer-Lemeshow's quality test results indicate a good level of fit. The contingency matrix indicates that $94.26 \%$ of the empirical observations are correctly classified.

Table 1. Contingency Matrix Table at 50\% Threshold Observed.

\begin{tabular}{llll}
\hline Observed Predicted & Healthy DFS & DFS in financial distress & Total \\
\hline Healthy DFS & $76(\mathrm{~A})$ & $7^{3}(\mathrm{~B})$ & 83 \\
DFS in financial distress & $7^{4}(\mathrm{C})$ & $154(\mathrm{D})$ & 161 \\
Total & 83 & 161 & 244 \\
\hline
\end{tabular}

Source: results of the study.

Following the analysis of the results obtained above, we note that the probabilities of the two errors (first and second type) are very low; in other words, the probability that the model does not indicate a financial difficulty that a DFS is going through and therefore obtain a false signal is very negligible. On the other hand, the probabilities of having good signals are very high compared to those of the two types of errors.

Table 2. Predictions table.

\begin{tabular}{ll}
\hline Probability of being in difficulty with no warning signal issued: type I error $=\mathrm{C} /(\mathrm{C}+\mathrm{D})$ & $4,35 \%$ \\
Probability of wrong warning signal: Type II error $=\mathrm{B} /(\mathrm{A}+\mathrm{B})$ & $8,43 \%$ \\
Probability of being healthy with no wrong warning signal $=\mathrm{A} /(\mathrm{A}+\mathrm{B})$ & $91,57 \%$ \\
Probability of being in difficulty with right warning signal issued $=\mathrm{D} /(\mathrm{C}+\mathrm{D})$ & $95,65 \%$ \\
Right classification $=(\mathrm{A}+\mathrm{D}) /(\mathrm{A}+\mathrm{B}+\mathrm{C}+\mathrm{D})$ & $94,26 \%$ \\
\hline
\end{tabular}

Source: Results of the study.

The estimation of the model parameters presented on table 3, reveals that all explanatory variables are significant. However, explanatory variables can be classified into two categories: those with positive coefficients (PAR, PCTA, LPOL) and the rest with negative coefficients (ERCR, OIOE, LCD, ODTA, and PM).

Table 3. Results of the binomial Logit model regression.

\begin{tabular}{llllll}
\hline Variables & Coefficients & Standard deviation & Statistics of Wald & Probability & Odds Ratio \\
\hline Constant & 56,61336 & 12,39413 & 4,57 & 0,000 & $3,86 \mathrm{e}+24$ \\
ERCR & $-91,54507$ & 19,21565 & $-4,76$ & 0,000 & $1,75 \mathrm{e}-40$ \\
PAR & 21,27881 & 5,312235 & 4,01 & 0,000 & $1,74 \mathrm{e}+09$ \\
PCTA & 465,9108 & 100,2162 & 4,65 & 0,000 & $4,5 \mathrm{e}+203$ \\
LPOL & 258,7806 & 55,4613 & 4,67 & 0,000 & $2,4 \mathrm{e}+112$ \\
OIOE & $-0,2648016$ & 0,100444 & $-2,64$ & 0,7673582 \\
LCD & $-14,23187$ & 3,260892 & $-4,36$ & $6,59 \mathrm{e}-07$ \\
ODTA & $-27,07535$ & 6,829489 & $-3,96$ & $1,74 \mathrm{e}-12$ \\
PM & 2,885122 & $-3,77$ & 0,00000187 \\
Number of observations & & 244 & 0,000 & \\
Pseudo-R2 (Mc Fadden's) & & 0,8094 & 0,000 & \\
LR Chi-square (8) & & 253,26 & & \\
Likelihood Ratio & & 0,0000 & \\
Test of Pearson and Hosmer-Lemeshow & & & & \\
Pearson chi2 (235) & & 219,27 & \\
Likelihood Ratio & & 0,7616 & & \\
\hline
\end{tabular}

Source: Results of the study.

\footnotetext{
3 Type II error.

4 Type I error.
} 
The results show that all the exogenous variables used in this regression are statistically significant at $1 \%$ level. Two types of variables can be distinguished by the nature of their probability to influence the bankruptcy of a microfinance institution.

The first category consists of factors with positive coefficients according to Table 3 above. Such factors include the portfolio at risk (PAR), loan provisions over outstanding loans (LPOL) and provisions over total assets (PCTA). These three variables are linked to the quality of the credit portfolio and reflect the control of the credit activity from the allocation step to the collection stage. Any increase in each of these ratios leads to an increase in the probability of difficulty for the DFS. An increase in the PAR variable represents a deterioration of the credit portfolio which decapitalizes the DFS, thus increasing its insolvency risk.

The second category of factors comprises those having a negative link with the probability of difficulty for DFS. These are the equity risk coverage ratio (ERCR), operating income on owner's equity (OIOE), profit margin (PM), loan coverage by deposits (LCD), and the outstanding deposits on total assets (ODTA). An increase in each of these ratios leads to a decrease in the probability of difficulty for the DFS. These ratios provide information on the importance of the financing structure of MFIs. Pulling sufficient shareholder's equity and deposits and also controlling operating cost are then a necessary condition to reduce the risk of bankruptcy for microfinance institutions.

\section{Conclusion}

In summary, the difficulties experienced by DFS depend on their ability to control the risks associated with the credit portfolio, to attract deposits to finance loans at lower cost, and to control operating expenses and improve margins. These factors also depend on the quality of management in terms of selecting the best projects to invest in, monitoring after funding, and of the systematic risks attached to the macroeconomic environment. The early warning model obtained implies that variables related with banking crises noted by the literature, notably, the quality of the portfolio and governance (O.C.C., [15]; Llewellyn, [12]; Taccolalapierre, [18]) are to some extent a match with the DFS sector. The negative relation between the financial default and the operating income on owner's equity (OIOE) and the profit margin (PM) align with Ayele [6]'s finding that keeping operational costs low improves the MFI's viability. Similarly, financial difficulty's determination by the portfolio at risk, the loan provisions over outstanding loans and the provisions over total assets confirm Ayayi [5]'s result that write-offs are a good determinant of MFI's credit risk.

Thus, the more protected are the DFSs from going bankrupt, the stronger is the local development because these institutions directly interact with the basic actors that are households with low incomes. Providing these segments of the population with long-term access to financial services that help them engage in income generating activities and employment is a factor that helps them reduce poverty and improve their standard of living. This is the reason why DFSs play such an important role in the development of communities that benefit from their services.

The results acknowledge that the prudential ratios published by the $B C E A O$ are relevant in preventing MFI's default. They function to enforce the quality of the credit portfolio, and to strengthen the owner's equity and the need for good governance.

\section{References}

[1] Adokpo K. K., 2010, "Contribution of the consolidation of equity capital to the control of the insolvency risk of microfinance institutions in Togo", Dissertation for the Master in Banking and Financial Studies, COFEB, Dakar.

[2] Ahumada, A., Bulnevich, C., 2001, "Some measures of financial fragility in the Chilean banking system: An early warning indicators application", Banking financial integration and international crisis, Central Bank of Chile.

[3] Altman E. I., 1968, "Financial Ratios, Discriminant Analysis and the Prediction of Corporate Bankruptcy", The Journal of Finance, 23, 4, pp. 589-609.

[4] Angora A. et Tarazi A., 2011, " Crises bancaires dans les pays de l'UEMOA: un système d'alerte avancée fondé sur une approche logit multinomiale ", Brussels Economic Review, 54, 1 .

[5] Ayayi G. A. 2012, "Credit assessment in the microfinance industry", Economics of Transition, 20, 1, pp 37-72.

[6] Ayele G. T. 2015, "Microfinance Institutions in Ethiopia, Kenya and Uganda: Loan Outreach to the Poor and the Quest for Financial Viability", African Development Review, 27, 2, pp 117-129.

[7] Demirgüc-Kunt A., Detragiache E., 2005, "Cross-country Empirical Studies of Systemic Bank Distress: A Survey", National Institute Economic Review, National Institute of Economic and Social Research, 192, pp. 68 (16).

[8] Eichengreen B., Arteta C., 2000, "Banking Crises in Emerging Markets: Presumptions and Evidence", Institute of Business and Economic Research, Center for International and development Economics Research, University of California.

[9] Evans O., Leone A., Gill M., Hilbers P., 2000, "Macro prudential Indicators of Financial System Soundness", IMF, Occasional Paper, $\mathrm{N}^{\circ} 192$.

[10] Gonzalez-Hermosillo B., 1999, " Crises bancaires: se doter d'indicateur d'alerte avancée ", IMF Finance \& Development FMI.

[11] Hardy D., Pazarbasioglu C., 1998, "Leading Indicators of Banking Crises: Was Asia Different? International Monetary Fund, Monetary and Exchange Affairs department, WP/98/91.

[12] Llewellyn D. 2002, "An analysis of the causes of recent banking crises" The European journal of finance, 8, 2 pp. 152175. 
[13] Martin D., 1977, "Early Warning of Bank Failure: A Logit Regression Approach", Journal of Banking and Finance, 1, pp. 249-276.

[14] N'dassim T. S., 2006, "The determinants of crises and bankruptcies of microfinance institutions in Togo", Dissertation for the Master in Banking and Financial Studies, COFEB, Dakar.

[15] O.C.C., 1988, "Bank Failure an Evaluation of Factors Contributing to the Failure of National Banks». Office of the Comptroller of the currency.
[16] Putu Astawa, Gde Raka Sukawati, Triyuni N.., Nyoman Abdi (2016), "Performance in Microfinance Institution in harmony Cultural Perspective in Bali", Procedia - Social and Behavioral Sciences 219, pp 113-120.

[17] Sinkey J. F., 1975, "A multivariate statistical analysis of the characteristics of problem banks", Journal of Finance 30, 2136.

[18] Taccola-lapierre S., 2007, " La crise du subprime", Region et Développement, 26, pp. 52-63. 